\title{
PENENTUAN NILAI HARGA WAJAR SAHAM DENGAN MENGGUNAKAN METODE GORDON GROWTH MODEL
}

\author{
Antoni $^{1}$, Ratih Juwita ${ }^{2}$, Aprilia Putri Wijayanti ${ }^{3}$ \\ ${ }^{1,3}$ Program Studi Manajemen, Fakultas Ekonomi, Universitas Gunadarma, Indonesia \\ ${ }^{2}$ Program Studi Akuntansi, Fakultas Ekonomi, Universitas Gunadarma, Indonesia \\ E-mail : antoni@staff.gunadarma.ac.id ${ }^{1}$,juwitaratih9@gmail.com², \\ apriliaputri983@gmail.com ${ }^{3}$
}

\section{Abstrak}

Latar belakang: Penilaian harga wajar saham bertujuan untuk memilih saham yang overvalued dan undervalued.

Tujuan penelitian: Penelitian ini bertujuan untuk mengetahui nilai harga wajar saham pada PT. Mitra Adiperkasa, Tbk pada tahun 2018, dan untuk mengetahui harga wajar saham berada pada undervalued atau overvalued.

Metode penelitian: Metode penulisan yang dilakukan dengan menggunakan analisis kuantitatif dengan menggunakan data sekunder yang telah diolah dan dipublikasikan. Adapun data yang diperoleh berasal dari www.idx.co.id, www.reuters.com, www.damodaran.com, www.bi.go.id. Untuk mengetahui harga wajar saham dan pengambilan keputusan investasi, menggunakan metode Gordon growth model yang terdiri dari perhitungan required rate of return, expected growth rate, dan value of stock serta membandingkan harga wajar dengan harga pasar saham tersebut. Kesimpulan: Berdasarkan perhitungan dan analisis yang telah dilakukan pada PT. Mitra Adiperkasa, Tbk maka dapat disimpulkan bahwa harga wajar saham PT. Mitra Adiperkasa, Tbk pada tahun 2018 sebesar Rp. 144,- per lembar saham dan menunjukkan bahwa harga wajar saham bersifat overvalued.

Kata Kunci: Harga Wajar Saham, Gordon Growth Model, Required rate of return

\section{Abstract}

Background: The assessment of the fair price of shares aims to select overvalued and undervalued stocks.

Research objectives: This study aims to determine the fair price value of shares in PT. Mitra Adiperkasa, Tbk in 2018, and to find out the fair price of the stock is undervalued or overvalued.

Research method: The writing method is carried out using quantitative analysis using secondary data that has been processed and published. The data obtained came from www.idx.co.id, www.reuters.com, www.damodaran.com, www.bi.go.id. To determine the fair price of shares and make investment decisions, use the Gordon growth model method which consists of calculating the required rate of return, expected growth rate, and value of stock and comparing the fair price with the stock market price.

Conclusion: Based on the calculations and analyzes that have been carried out at PT. Mitra Adiperkasa, Tbk, it can be concluded that the fair price of PT. Mitra Adiperkasa, Tbk in 2018 amounted to Rp. 144,- per share and indicates that the fair price of the shares is overvalued.

Keywords: Fair Price of Stock, Gordon Growth Model, Required rate of return

Diterima: 26-11-2020; Direvisi: 6-12-2020; Disetujui: 6-12-2020: 


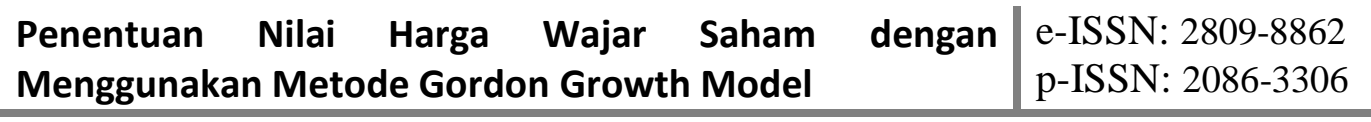

\section{PENDAHULUAN}

Investasi menjadi alternatif pilihan bagi masyarakat modern saat ini dalam mengelola dan merencanakan keuangannya (Yushita, 2017). Investasi pada instrumen pasar modal menjadi salah satu cara yang diminati oleh para pemilki modal di Indonesia saat ini (Batubara, 2020). Pasar modal mempunyai peranan yang sangat penting bagi perekonomian negara (Permata \& Ghoni, 2019). Pemerintah dalam hal ini berupaya meningkatkan peran pasar modal karena peranannya dalam pembangunan nasional sebagai salah satu sumber pembiayaan bagi dunia usaha dan sarana investasi bagi masyarakat (Juliati, 2015). Pasar modal juga berperan sebagai sarana dalam mencari dana yang bersifat jangka panjang seperti penerbitan saham dan obligasi. Harga-harga saham yang wajar dibeli dan disesuaikan dengan kemampuan investor untuk berinvestasi sehingga investor mendapat keuntungan yang maksimal dari investasi yang didapatkannya tersebut.

Dari sekian banyak investasi, investasi saham merupakan jenis investasi yang banyak menguntungkan daripada jenis investasi lainnya seperti misalnya investasi dalam bentuk aktiva seperti emas, perak, real estate, atau investasi dalam bentuk deposito (Dipraja, 2011). Investasi saham merupakan investasi yang likuid sekali, karena perubahan portofolio saham sangat cepat (Puspitaningtyas, 2015). Akibatnya tingkat keuntungan yang dapat diraih cukup besar dibandingkan dengan investasi lainnya yang bersifat permanen.

Perusahaan retail terutama yang bergerak di bidang fashion atau lifestyle merupakan salah satu kategori sektor industri di Bursa Efek Indonesia (BEI) yang mempunyai peluang untuk tumbuh dan berkembang. Barang fashion menjadi industri yang penting bagi perkembangan perekonomian bangsa (Romindo et al., 2019). Hal ini tidak terlepas dari perusahaan-perusahaan yang bergerak dalam industri barang fashion di Indonesia. Tidak bisa dipungkiri bahwasanya dalam proses produksi barang fashion dibutuhkan banyak sumber daya termasuk di dalamnya smber daya manusia. Jumlah perusahaan retail yang terdaftar di Bursa Efek Indonesia cukup banyak. perusahaan retail yang terkemuka dengan kegiatan operasi yang mencakup seluruh tahapan produksi (Aziatul et al., 2020).

PT Mitra Adiperkasa, Tbk dengan kode emiten MAPI merupakan salah satu perusahaan yang bergerak dalam industri retail. Berdiri pada tanggal 23 Januari 1995. Saat ini, MAP memiliki banyak portofolio retail yang hampir sebagian besar merupakan merek populer internasional (Pratama, 2021). Sebagian besar produk dengan market lifestyle hampir tersebar di seluruh wilayah Indonesia. Bahkan, higga kini perusahaan sudah membuka lebih dari 2600 gerai retail dari total kseluruhan merek. Beberapa kategori dari produk retail yang ditawarkan seperti fashion, kids, food and beverage, sports dan produk populer lainnya. Bahkan, PT Mitra Adiperkasa, Tbk juga menawarkan department store yang memiliki pangsa pasar menengah atas.

Sejak mulai beroperasi pada tahun 1995, MAPI mengalami pertumbuhan industri yang sangat pesat. Bahkan, jumlah gerai terus bertambah dengan diikuti merek besar yang masuk dalam retail (Basri, 2012). Ini yang membuat perusahaan mengambil Dalam hal ini penulis ingin mengetahui mengenai keberhasilan perusahaan PT Mitra Adiperkasa, Tbk yang diukur melalui harga sahamnya. PT Mitra Adiperkasa, Tbk merupakan langkah besar untuk melakukan perdagangan saham pertama kali atau IPO. PT Mitra Adiperkasa, Tbk melakukan IPO pertama kali pada 10 November 2004. Jumlah saham yang pertama kali diterbitkan terdiri dari saham penawaran mencapai 500.000.000 lembar dan saham pendiri sebanyak 1.160.000.000. 
Keseluruhan dari saham yang terdaftar pada penawaran pertama kali mencapai 1.660.000.000. Jumlah penawaran saham ini terkonversi hingga $0,12 \%$ dari total keseluruhan yang dimiliki oleh perusahaan. Pada saat penawaran pertama kali, nilai saham yang diberikan 625 per lembar. Setelah penawaran, perusahaan mendapatkan pendanaan higga 312.500.000.000. Dana ini digunakan untuk pengembangan bisnis hingga saat ini. Biro administrasi efek yang terintegrasi degan perusahaan ini yaitu PT Datindo Entrycom.

Dalam melakukan analisis pemilihan saham, terdapat dua pendekatan yang sering digunakan untuk menganalisis harga saham, yaitu analisis fundamental dan analisis teknikal (Amanda \& Pratomo, 2013). Salah satu metode valuasi saham dan analisis fundamental saham adalah penilaian harga wajar saham menggunakan metode Gordon Growth. Penelitian ini bertujuan untuk mengetahui nilai harga wajar saham pada PT. Mitra Adiperkasa, Tbk pada tahun 2018, dan untuk mengetahui harga wajar saham berada pada undervalued atau overvalued (Alhakim, 2019).

\section{METODE PENELITIAN}

Jenis penelitian ini adalah penelitian empiris, metode analisis data yang dilakukan dalam penelitian ini adalah analisis kuantitatif dengan menggunakan data sekunder yang telah diolah dan dipublikasikan dari website resmi Bursa Efek Indonesia http://www.idx.co.id berupa laporan tahunan keuangan PT Mitra Adiperkasa, Tbk dari tahun 2015 sampai dengan tahun 2019. PT Mitra Adiperkasa, Tbk (MAPI) yang beralamat di Sahid Sudirman Center, Lt. 29, Jl. Jend. Sudirman Kav. 86, Jakarta 10220, Indonesia.

\section{HASIL DAN PEMBAHASAN}

\begin{tabular}{|c|c|c|c|c|c|}
\hline $\begin{array}{l}\text { (Dalam juta } \\
\text { rupiah) }\end{array}$ & 2014 & 2015 & 2016 & 2017 & 2018 \\
\hline Pendapatan & $5,852,453$ & $6,874,192$ & $6,968,294$ & $9,217,160$ & $9,204,287$ \\
\hline Laba kotor & $1,443,721$ & 686,009 & $1,094,888$ & $1,525,563$ & $1,677,530$ \\
\hline $\begin{array}{l}\text { Laba sebelum } \\
\text { pajak }\end{array}$ & 801,502 & 168,163 & 414,970 & 716,211 & 766,482 \\
\hline Laba bersih & 515,102 & 101,561 & 251,969 & 508,914 & 531,349 \\
\hline $\begin{array}{l}\text { Laba per saham } \\
\text { (dalam rupiah) }\end{array}$ & 102 & 14 & 34 & 68 & 71 \\
\hline $\begin{array}{l}\text { Dividen } \\
\text { (rp/saham) }\end{array}$ & 56 & 4 & 10 & 24 & 21 \\
\hline $\begin{array}{l}\text { Modal kerja } \\
\text { bersih }\end{array}$ & $3,039,446$ & $2,445,246$ & $2,176,675$ & $3,549,440$ & $3,028,036$ \\
\hline Jumlah aktiva & $9,752,477$ & $9,279,683$ & $9,548,631$ & $11,876,309$ & $15,117,948$ \\
\hline $\begin{array}{l}\text { Jumlah } \\
\text { kewvajiban }\end{array}$ & $4,144,235$ & $3,908,615$ & $3,894,946$ & $5,814,816$ & $8,596,067$ \\
\hline Ekuitas & $5,608,242$ & $5,371,068$ & $5,653,685$ & $6,061,493$ & $6,521,881$ \\
\hline $\begin{array}{l}\text { Belanja modal } \\
\text { Rasio dalam } \\
(\%)\end{array}$ & 437,815 & 649,120 & 535,037 & 779,812 & $1,167,128$ \\
\hline $\begin{array}{l}\text { Marjin laba } \\
\text { kotor }\end{array}$ & 22 & 10 & 16 & 17 & 15 \\
\hline $\begin{array}{l}\text { Marjin laba } \\
\text { usaha }\end{array}$ & 14 & 1 & 6 & 8 & 7 \\
\hline $\begin{array}{l}\text { Marjin laba } \\
\text { bersih }\end{array}$ & 9 & 1 & 4 & 5 & 5 \\
\hline $\begin{array}{l}\text { Laba terhadap } \\
\text { alktiva. }\end{array}$ & 7 & 1 & 3 & 4 & 4 \\
\hline $\begin{array}{l}\text { Laba terhadap } \\
\text { elcuitas }\end{array}$ & 12 & 13 & 2 & 8 & 9 \\
\hline $\begin{array}{l}\text { Kewajiban } \\
\text { terhadap } \\
\text { elkuitas }\end{array}$ & 61 & 74 & 73 & 96 & 132 \\
\hline $\begin{array}{l}\text { Kewajiban } \\
\text { terhadap alktiva }\end{array}$ & 25 & 42 & 42 & 49 & 57 \\
\hline
\end{tabular}

Gambar 1. Ikhtisar Keuangan 


\section{Required Rate of Return}

Required Rate of Return merupakan tingkat pengembalian yang disyaratkan oleh investor sebagai konsekuensi atas investasi pada saham perusahaan. Pendekatan Required Rate of Return yang digunakan oleh penulisan ini adalah Capital Asset Pricing Model (CAPM) yang menjadi tingkat diskonto dalam perhitungan harga wajar saham menggunakan metode Dividend Discount Model.

Perhitungan :

$=0,05+(1,85 \times 0,086)$

$=0,05+0,1591$

$=0,2091$ atau $20,91 \%$

\begin{tabular}{|c|c|c|}
\hline No. & Tahun & Required rate of return \\
\hline 1 & 2014 & 0,2341 atau $23,41 \%$ \\
\hline 2 & 2015 & 0,2066 atau $20,66 \%$ \\
\hline 3 & 2016 & 0,2016 atau $20,16 \%$ \\
\hline 4 & 2017 & 0,2191 atau $21,91 \%$ \\
\hline 5 & 2018 & 0,2091 atau $20,91 \%$ \\
\hline
\end{tabular}

Gambar 2. Hasil Perhitungan Required Rate ofReturn

\section{Expected Growth Rate}

Salah satu bagian penting ketika seorang analis atau investor melakukan valuasi adalah menentukan tingkat pertumbuhan yang dipergunakan sebagai dasar untuk memproyeksikan revenue dan earnings (Erianda et al., 2011). Estimasi pertumbuhan digunakan untuk menjaga agar pertumbuhan dividen yang diterima sesuai dengan estimasi (Erianda et al., 2011). Estimasi pertumbuhan yang sangat sensitif karena jika salah mengestimasi pertumbuhan harga wajar saham tersebut tidak akan sesuai atau jauh dari harga pasar (Hendrata \& Haryanto, 2013). Estimasi pertumbuhan dapat dihitung sebagai berikut: Perhitungan :

$=(1-0,2957) \times 0,09$

$=0,7122 \times 0,09$

$=0,0633$ atau $6,33 \%$ 


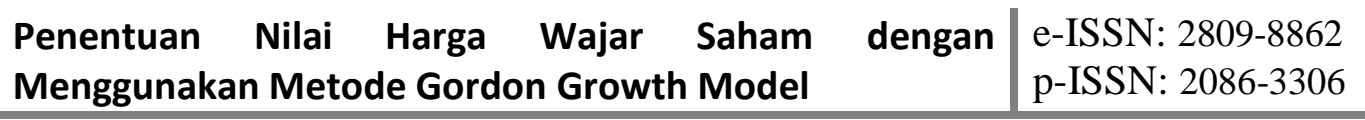

\begin{tabular}{c|cc} 
No. & Tahun & Expecled growth rate \\
\hline $\mathbf{1}$ & 2014 & 0,0054 atau $0,54 \%$ \\
$\mathbf{2}$ & 2015 & 0,0928 atau $9,28 \%$ \\
$\mathbf{3}$ & 2016 & 0,0141 atau $1,41 \%$ \\
$\mathbf{4}$ & 2017 & 0,0517 atau $5,17 \%$ \\
$\mathbf{5}$ & 2018 & 0,0633 atau $6,33 \%$
\end{tabular}

Gambar 3. Hasil Perhitungan Expected GrowthRate

\section{Value of Stock}

Value of Stock merupakan alat analisis yang digunakan untuk menghitung harga wajar saham perusahaan (Arista \& Astohar, 2012). Value of Stock terdiri dari tiga unsure yaitu Dividend per Share, Required Rate of Return dan Expected Growth Rate. Perhitungan Value of Stock sebagai berikut:

Perhitungan :

Value of Stock

$=21 / 0,2091-0,6333$

$=21 / 0,1458$

$=144$

\begin{tabular}{c|cc} 
No. & Tahun & Value of stock \\
\hline $\mathbf{1}$ & 2014 & Rp 220 \\
$\mathbf{2}$ & 2015 & $\mathrm{Rp} \mathrm{35}$ \\
$\mathbf{3}$ & 2016 & $\mathrm{Rp} \mathrm{133}$ \\
$\mathbf{4}$ & 2017 & $\mathrm{Rp} \mathrm{151}$ \\
$\mathbf{5}$ & 2018 & $\mathrm{Rp} \mathrm{144}$ \\
Gambar 4. Hasil Perhitungan Value of Stock
\end{tabular}

Berdasarkan hasil perhitungan Value Of Stock dapat diketahui harga pasar saham per lembar pada tahun 2015 - 2018 PT Mitra Adiperkasa, Tbk mengalami kenaikan dan penurunan yang fluktuatif dan ditahun 2019 kembali mengalami kenaikan. Namun jika dibandingkan dengan harga pasar pertahunnya, harga wajar saham PT Mitra Adiperkasa, Tbk lebih rendah dikarenakan permintaan akan saham sangat tinggi sementara saham yang beredar masih belum terlalu banyak dan menyebabkan harga pasar menjadi semakin tinggi.

\section{KESIMPULAN}

Berdasarkan penentuan penelitian, maka dapat ditarik kesimpulan berdasarkan perhitungan harga wajar saham PT Mitra Adiperkasa, Tbk menggunakan metode Gordon Growth Model didapati bahwa harga wajar saham PT Mitra Adiperkasa, Tbk tahun 2018 sebesar Rp 144 per lembar saham. Berdasarkan perbandingan antara harga wajar saham dan harga pasar saham PT Mitra Adiperkasa, Tbk pada tahun 2018 menunjukkan bahwa saham PT Mitra Adiperkasa, Tbk bersifat Overvalued. Ditahun 2014 - 2017 saham PT Mitra Adiperkasa, Tbk juga bersifat Overvalued karena harga pasar sahamnya rendah. Karena harga saham PT Mitra Adiperkasa, Tbk pada saat sekarang ini lebih tinggi dari harga wajarnya, oleh karena itu saham tersebut belum layak dibeli (buy) oleh calon investor dan layak dijual (sell) bagi investor yang telah memiliki saham. 


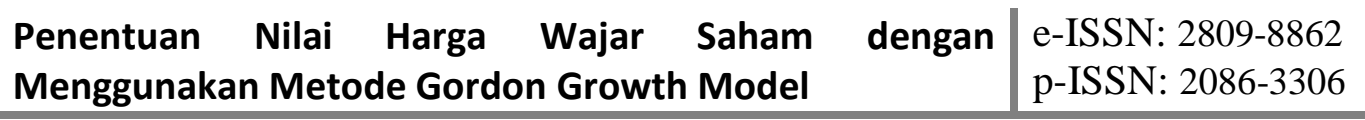

\section{BIBLIOGRAFI}

Alhakim, G. F. (2019). Analisis Fundamental Perusahaan Serta Penilaian Saham Dengan Metode Price Earning Ratio Dan Price Book Value Dalam Rangka Menilai Harga Wajar Saham Dan Keputusainvestasi (Studi PadaPerusahaan Konstruksi yang Terdaftar di Daftar Efek Syariah (DES) Periode 2015-2017). UIN Raden Intan Lampung.

Amanda, W., \& Pratomo, W. A. (2013). Analisis Fundamental dan Resiko Sistematik Terhadap Harga Saham Perbankan yang Terdaftar Pada Indeks LQ 45. Jurnal Ekonomi Dan Keuangan, 1(3), 14728.

Arista, D., \& Astohar, A. (2012). Analisis Faktor-Faktor Yang Mempengaruhi Return Saham. Jurnal Ilmu Manajemen Dan Akuntansi Terapan (JIMAT), 3(1).

Aziatul, R., Munandar, A., Veronica, M., \& Meihazura, Y. (2020). Pengaruh Perputaran Piutang dan Perputaran Persediaan Terhadap Profitabilitas Pada Perusahaan Sub Sektor Perdagangan Eceran yang Terdaftar Di Bursa Efek Indonesia (Bei) Periode 2014-2018. Jurnal Keuangan Dan Bisnis, 18(1), 116-128.

Basri, M. C. (2012). Rumah Ekonomi Rumah Budaya. Gramedia Pustaka Utama.

Batubara, Y. (2020). Analisis Maslahah: Pasar Modal Syariah Sebagai Instrumen Investasi Di Indonesia. HUMAN FALAH: Jurnal Ekonomi Dan Bisnis Islam, 2(7).

Dipraja, S. (2011). Siapa Bilang Investasi Emas Butuh Modal Gede? Tangga Pustaka.

Erianda, B., Siswanto, A., \& Ainy, R. N. (2011). Penentuan harga wajar saham PT Telekomunikasi Indonesia tbk dengan metode Gordon Growth Model. Proceeding PESAT (Psikologi, Ekonomi, Sastra, Arsitektur \&Sipil).

Hendrata, A. S., \& Haryanto, A. M. (2013). Analisis Pengaruh Roe, Growth, \& Working Capital Terhadap Overvalued Saham Lq 45 Pada Perusahaan Non Perbankan Yang Tercatat Di Bei Periode 2008-2010. Diponegoro Journal of Management, 2(2), 6071.

Juliati, Y. S. (2015). Peranan Pasar Modal Dalam Perekonomian Negara. HUMAN FALAH: Jurnal Ekonomi Dan Bisnis Islam, 2(1), 95-112.

Permata, C. P., \& Ghoni, M. A. (2019). Peranan Pasar Modal Dalam Perekonomian Negara Indonesia. Jurnal AkunStie (JAS), 5(2), 50-61.

Pratama, B. Y. (2021). Prediksi Financial Distress Menggunakan Rasio Keuangan Dan Zmijewski (Studi Pada Perusahaan Ritel Yang Terdaftar Di Bursa Efek Indonesia). Universitas Brawijaya.

Puspitaningtyas, Z. (2015). Prediksi Risiko Investasi Saham. Pandiva Buku.

Romindo, R., Muttaqin, M., Saputra, D. H., Purba, D. W., Iswahyudi, M., Banjarnahor, A. R., Kusuma, A. H. P., Effendy, F., Sulaiman, O. K., \& Simarmata, J. (2019). ECommerce: Implementasi, Strategi dan Inovasinya. Yayasan Kita Menulis.

Yushita, A. N. (2017). Pentingnya literasi keuangan bagi pengelolaan keuangan pribadi. Nominal: Barometer Riset Akuntansi Dan Manajemen, 6(1), 11-26.

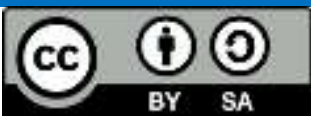

This work is licensed under a Creative Commons Attribution-ShareAlike 4.0 International License 